\title{
Combining microorganisms in inoculants is agronomically important but industrially challenging: case study of a composite inoculant containing Bradyrhizobium and Azospirillum for the soybean crop
}

\author{
Marcos Vinicios Conceição Garcia ${ }^{1,2} \mathbb{0}$, Marco Antonio Nogueira ${ }^{2}$ and Mariangela Hungria ${ }^{1,2^{*}}$ (D)
}

\begin{abstract}
The increasing global perception of the importance of microbial inoculants to promote productivity and sustainability in agriculture prompts the adoption of bio-inputs by the farmers. The utilization of selected elite strains of nitrogenfixing and other plant-growth promoting microorganisms in single inoculants creates a promising market for composite inoculants. However, combining microorganisms with different physiological and nutritional needs requires biotechnological development. We report the development of a composite inoculant containing Bradyrhizobium diazoefficiens and Azospirillum brasilense for the soybean crop. Evaluation of use of carbon sources indicates differences between the microbial species, with Bradyrhizobium growing better with mannitol and glycerol, and Azospirilum with malic acid and maleic acid, allowing the design of a formulation for co-culture. Species also differ in their growth rates, and the best performance of both microorganisms occurred when Azospirillum was inoculated on the third day of growth of Bradyrhizobium. The composite inoculant developed was evaluated in five field trials performed in Brazil, including areas without and with naturalized populations of Bradyrhizobium. The composite inoculant resulted in symbiotic performance comparable to the application of the two microorganisms separately. In comparison to the single inoculation with Bradyrhizobium, co-inoculation resulted in average increases of $14.7 \%$ in grain yield and $16.4 \%$ in total $\mathrm{N}$ accumulated in the grains. The performance of the composite inoculant was similar or greater than that of the non-inoculated control receiving a high dose of $\mathrm{N}$-fertilizer, indicating the importance of the development and validation of inoculants carrying multiple beneficial microorganisms.
\end{abstract}

Keywords: Biological nitrogen fixation, Plant-growth promoting bacteria, Inoculation, Industrial microbiology

\section{Introduction}

The global search for low-cost agricultural technologies that can help increase food offer under sustainable production models is becoming more relevant (Sá et al.

\footnotetext{
*Correspondence: mariangela.hungria@embrapa.br; biotecnologia. solo@hotmail.com

1 Department of Biotechnology, Universidade Estadual de Londrina, C.P. 10011, Londrina, Paraná 86057-970, Brazil

Full list of author information is available at the end of the article
}

2017). Microorganisms are major players in this vision of agriculture of the future and, in fact, in the last decade changes in farmers' perception have already been noticed, reflecting in increased adoption of microbial bio-inputs (Malusá and Vassilevde 2014; de Bruijn 2015; Fukami et al. 2018a; Bellabarba et al. 2019; Santos et al. 2019).

In the coming years, Brazil should consolidate its position as a major player in the production and commercialization of food, in addition to standing out in the 
production of fibers, biofuels and biomass. Indeed, the country has just become the world's largest soybean producer [Glycine $\max$ (L.) Merr.] (USDA 2020). The effort in the development of research with microorganisms of agricultural importance has been a constant in the country, and a great example is the adoption of the process of biological $\mathrm{N}_{2}$ fixation (BNF) for the economic viability of the soybean crop, making it independent of $\mathrm{N}$-fertilizers. The savings provided by the BNF with the soybean crop in Brazil are estimated today at US \$ 14.4 billion per crop. Noticeable is also the environmental contribution, lowering the emission of greenhouse gases and reducing the leaching of nitrate to rivers, water reservoirs, groundwater, and lakes (Hungria et al. 2013a; Hungria and Mendes 2015; Sá et al. 2017; Hungria and Nogueira 2019).

Considering the soybean crop, three major milestones in the recent history of BNF in Brazil can be highlighted. The first is the validation of the reinoculation technology, with an average $8 \%$ increase in grain yield by inoculation every year (Hungria and Mendes 2015; Hungria and Nogueira 2019; Hungria et al. 2006, 2007, 2020). The second came from the selection of the first commercial strains of Azospirillum brasilense for grasses, with the release of the first commercial product in 2009 (Hungria et al. 2010; Santos et al. 2019, 2021). The third major milestone was the development of the technology of co-inoculation for the soybean in 2013, consisting of the combination of strains of Bradyrhizobium spp. highly efficient in fixing nitrogen and strains of $A$. brasilense with high phytohormone production capacity (Hungria et al. 2013b, 2015). In the short period of five years, coinoculation has been adopted on average in $25 \%$ of the 36 million ha cropped with this legume (Santos et al. 2021).

There is no doubt that the combination of microbial inoculants can provide excellent results, justifying their great potential of being employed worldwide (Bashan 1998; Juge et al. 2012; Malusá and Vassilevde 2014; Fukami et al. 2017; Bellabarba et al. 2019; Santos et al. 2019, 2021). Farmers, however, demand more practicality at sowing, and are requesting commercial products that combine various microorganisms. However, it is not easy to combine microorganisms with different nutritional requirements and growth rates. A strategy is presented in this study, where the stages of development and field validation of a composite inoculant containing Bradyrhizobium and Azospirillum for the soybean crop are presented.

\section{Material and methods}

\section{Strains used in the study}

The study included the strains of Bradyrhizobium japonicum SEMIA 5079 (=CNPSo 7,=CPAC 15), Bradyrhizobium diazoefficiens SEMIA 5080 (=CNPSo 6,=CPAC
7), and Azospirillum brasilense strains Ab-V5 (=CNPSo 2083) e Ab-V6 (=CNPSo 2084), all employed in commercial inoculants in Brazil for legumes and grasses. The strains are deposited in the "Diazotrophic and Plant Growth Promoting Bacteria Culture Collection of Embrapa Soja" (WFCC Collection \# 1213, WDCM Collection \# 1054).

\section{Development of the inoculant Preparation of pre-inocula of Bradyrhizobium spp. and A. brasilense}

Pre-inocula were prepared to initiate bacterial cultures for the studies of $\mathrm{C}$ sources and inoculation time.

Strains SEMIA 5079 and SEMIA 5080 of Bradyrhizobium spp. were grown in modified-YM broth (Hungria et al. 2016), and A. brasilense strains Ab-V5 and Ab-V6 in modified-RC (Rojo Congo) broth (Santos et al. 2020), without Congo red, in $100 \mathrm{~mL}$ bottles. The samples were incubated at $28{ }^{\circ} \mathrm{C} \pm 2{ }^{\circ} \mathrm{C}$, for 5 days and 3 days, respectively, on a rotary shaker at $120 \mathrm{rpm}$. After growth, the cultures were centrifuged for $10 \mathrm{~min}$ at $6000 \mathrm{rpm}$. The supernatant was discarded and the pellet resuspended in $0.85 \% \mathrm{NaCl}$ saline solution and centrifuged again, under the same conditions. The supernatant formed in the second centrifugation was discarded, re-suspending the pellet in $40 \mathrm{~mL}$ of the respective media, in order to adjust the concentration to approximately $10^{9}$ cells $\mathrm{mL}^{-1}$ for Bradyrhizobium and $10^{8}$ cells $\mathrm{mL}^{-1}$ for Azospirillum. The concentration was adjusted by reading the optical density (O.D.) on a spectrophotometer at $600 \mathrm{~nm}$, according to growth curves previously prepared and available in the laboratory. Concentrations were read at O.D. 0.400 for SEMIA 5080, O.D. 0.600 for SEMIA 5079 (higher production of exopolysaccharides) and O.D. 0.600 for both strains of Azospirillum.

\section{Growth in different carbon sources and elaboration of a basic formulation of coinoculant}

In order to evaluate the ability to metabolize different carbon sources, $10 \mathrm{~mL}$ pre-inoculum of each strain were added to $100 \mathrm{~mL}$ of the appropriate medium, at $\mathrm{pH} 6.8$, containing different $\mathrm{C}$ sources (Table 1), in $500 \mathrm{~mL}$ flasks. Cultures were grown on a rotary shaker at $120 \mathrm{rpm}$, at $28{ }^{\circ} \mathrm{C} \pm 2{ }^{\circ} \mathrm{C}$. The number of colony forming units (CFU) present in each medium was determined from aliquots aseptically removed from the cultures at different intervals during growth, by means of the spread-plate technique (O'Hara et al. 2016), in modified-YMA solid medium (Hungria et al. 2016) for Bradyrhizobium and RC solid medium (Santos et al. 2020) for Azospirillum. In addition, O.D. and the $\mathrm{pH}$ of the culture media were also evaluated. 
Table 1 Composition of the culture media to verify the use of different sources of carbon by Bradyrhizobium japonicum, Bradyrhizobium diazoefficiens and Azospirillum brasilense

\begin{tabular}{|c|c|c|c|c|c|c|c|c|c|}
\hline \multirow[t]{2}{*}{ Component } & \multicolumn{9}{|c|}{ Treatments $\left(\mathrm{g} \mathrm{L}^{-1}\right)$} \\
\hline & $\mathrm{T} 1$ & $\mathrm{~T} 2$ & T3 & T4 & T5 & T6 & T7 & T8 & T9 \\
\hline $\mathrm{K}_{2} \mathrm{HPO} 4$ & 0.5 & 0.5 & 0.5 & 0.5 & 0.5 & 0.5 & 0.5 & 0.5 & 0.5 \\
\hline $\mathrm{MgSO}_{4} \cdot 7 \mathrm{H}_{2} \mathrm{O}$ & 0.2 & 0.2 & 0.2 & 0.2 & 0.2 & 0.2 & 0.2 & 0.2 & 0.2 \\
\hline $\mathrm{NaCl}$ & 0.1 & 0.1 & 0.1 & 0.1 & 0.1 & 0.1 & 0.1 & 0.1 & 0.1 \\
\hline Yeast extract & 0.0 & 0.5 & 0.5 & 0.5 & 0.5 & 0.5 & 0.5 & 0.5 & 0.5 \\
\hline Sucrose & 0.0 & 0.0 & 5.0 & 0.0 & 0.0 & 0.0 & 0.0 & 0.0 & 0.0 \\
\hline Glycerol & 0.0 & 0.0 & 0.0 & 5.0 & 0.0 & 0.0 & 0.0 & 0.0 & 0.0 \\
\hline Mannitol & 0.0 & 0.0 & 0.0 & 0.0 & 5.0 & 0.0 & 0.0 & 0.0 & 0.0 \\
\hline Glutamic acid & 0.0 & 0.0 & 0.0 & 0.0 & 0.0 & 5.0 & 0.0 & 0.0 & 0.0 \\
\hline Malic acid & 0.0 & 0.0 & 0.0 & 0.0 & 0.0 & 0.0 & 5.0 & 0.0 & 0.0 \\
\hline Citric acid & 0.0 & 0.0 & 0.0 & 0.0 & 0.0 & 0.0 & 0.0 & 5.0 & 0.0 \\
\hline Maleic acid & 0.0 & 0.0 & 0.0 & 0.0 & 0.0 & 0.0 & 0.0 & 0.0 & 5.0 \\
\hline
\end{tabular}

From the results obtained, six formulations were developed that allowed the growth of both Bradyrhizobium and Azospirillum.

\section{Determination of the sequence of inoculation of Bradyrhizobium and Azospirillum in the formulation of the composite inoculant}

Bradyrhizobium spp. and A. brasilense exhibit different growth rates. It is also known that the concentration of Azospirillum strains of Ab-V5 and Ab-V6, when used for co-inoculation of soybean, must be ten times lower than that of Bradyrhizobium spp to optimize growth and BNF (Hungria et al. 2013b). In order to achieve these conditions, co-cultivation tests were carried out with the two best formulations identified in the experiments of growth with different $\mathrm{C}$ sources, to determine the appropriate times for sequential inoculation of the two species.

The experiment started with the inoculation of $10 \mathrm{~mL}$ of pre-inoculum of Bradyrhizobium spp. at the con-

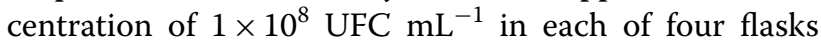
containing of $100 \mathrm{~mL}$ culture medium, and this was considered as the initial cultivation, or zero time. Following, $10 \mathrm{~mL}$ of the pre-inoculum of $A$. brasilense strains Ab-V5 and $\mathrm{Ab}-\mathrm{V} 6$ at the concentration of $1 \times 10^{7} \mathrm{UFC} \mathrm{\textrm {mL } ^ { - 1 }}$ were inoculated in the flasks containing Bradyrhizobium spp. growing for 2 (T1), 3 (T2) and 4 (T3) days. The control treatment consisted only of Bradyrhizobium spp., and received no $A$. brasilense.

The analyzes of cell concentration of the control treatment were performed from the second to the fifth day of cultivation of Bradyrhizobium spp., whereas, for the treatments of co-culture T1, T2 and T3, the analyzes were carried out after $24 \mathrm{~h}$ of each time of inoculation of $A$. brasilense. Growth assessments were carried out as described in the item of evaluation of growth with different carbon sources.

\section{Evaluation of the composite inoculant in field trials Treatments}

For the field experiments, the co-inoculant evaluated corresponded to the best formulation identified under laboratory conditions and carrying the strain of $B$. diazoefficiens SEMIA 5080 and A. brasilense Ab-V6.

The treatments evaluated were: T1-Non-inoculated control without N-fertilizer; T2-Non-inoculated control receiving $200 \mathrm{~kg}$ of $\mathrm{N} \mathrm{ha}^{-1}$ of $\mathrm{N}$-fertilizer (supplied as urea, $50 \%$ at sowing, and 50\% at flowering); T3-Peat inoculant (treatment required by Brazilian legislation, considered as "gold standard", e.g. Burton and Curley 1965) containing the strains of B. japonicum SEMIA 5079 and $B$. diazoefficiens SEMIA 5080, applied to supply $1.2 \times 10^{6}$ cells seed $^{-1}$; T4-Trademark commercial liquid inoculant containing the strains of $B$. japonicum SEMIA 5079 and $B$. diazoefficiens SEMIA 5080, applied to supply

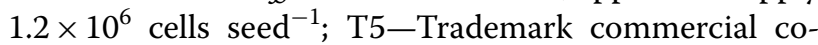
inoculant consisting of individual packs of Bradyrhizobium and Azospirillum, the first containing the strains of B. japonicum SEMIA 5079 and B. diazoefficiens SEMIA 5080 , applied to provide $1.2 \times 10^{6}$ cells seed $^{-1}$, and the second with $A$. brasilense Ab-V5 and Ab-V6, applied to supply $1.2 \times 10^{5}$ cells seed $^{-1}$; T6-Composite inoculant developed in this study applied to supply $1.2 \times 10^{6}$ cells seed- 1 of $B$. diazoefficiens SEMIA 5080 and $1.2 \times 10^{5}$ cells seed ${ }^{-1}$ of $A$. brasilense Ab-V6. An extra-treatment (T7), consisting of in-furrow application of a triple dose of the composite inoculant developed in this study was included in two sites. 


\section{Establishment and conduction of the field trials}

Five field trials were conducted in the 2017/2018 crop season, at five different sites; the geographic coordinates, climatic conditions, characteristics and soil classification of each location are presented in Additional file 1: Table S1.

At each site, between 40 and 60 days before the beginning of the experiment, 20 soil sub-samples were obtained, in the layers of $0-20$ and $20-40 \mathrm{~cm}$, to evaluate the chemical and soil granulometric properties of the soil.

The chemical analysis of the soils and the reference values were defined according to van Raij et al. (2001) and Silva (2009) and the results obtained are presented in Additional file 1: Tables S2 and S3. The C content in the soil was determined in an elementary analyzer Vario TOC Cube in air-dried and finely ground samples $(<0$, $02 \mathrm{~mm}$ ). This method is considered suitable for soils with high Fe content, due to its greater accuracy and reproducibility (Segnini et al. 2008). The results obtained are available in Additional file 1: Table S3. Regarding the granulometric analysis, the fractions of sand, silt and clay were determined according to Teixeira et al. (2017) and the results are shown in Additional file 1: Table S3.

According to the results obtained in the soil analysis, liming was performed, estimated to reach base saturation of $70 \%$ in Londrina, $60 \%$ in Lutécia, and $50 \%$ in the other sites (Embrapa Soja 2013). Approximately 30 days before sowing, weed control was carried out with the application of $2.5 \mathrm{~L} \mathrm{ha}^{-1}$ of glyphosate.

Immediately before sowing, fertilization was carried out with $300 \mathrm{~kg} \mathrm{ha}^{-1}$ of the formulation 00-20$20\left(60 \mathrm{~kg} \mathrm{ha}^{-1}\right.$ of $\mathrm{P}_{2} \mathrm{O}_{5}$ and $60 \mathrm{~kg} \mathrm{ha}^{-1}$ of $\mathrm{K}_{2} \mathrm{O}$ ) for all treatments. In treatment 2 (T2), non-inoculated control receiving $\mathrm{N}$-fertilizer, $100 \mathrm{~kg}$ of $\mathrm{N} \mathrm{ha}^{-1}$ (urea) were applied to the surface of the plot and lightly incorporated.

The population of rhizobia symbionts of soybean in the $0-10 \mathrm{~cm}$ soil layer was evaluated in samplings carried out in the same way as for the chemical analysis and soil granulometry, but collected on the sowing day. The population was estimated by the most probable number (MPN) method, with counts on soybean plants of the cultivar BRS 1010IPRO (Hungria et al. 2016). In the same samples, the population of diazotrophic bacteria was also evaluated by MPN method in semi-solid NFb culture medium (Döbereiner et al. 1976). The results obtained are presented in Additional file 1: Table S3.

The soybean cultivar used in the field experiments was the Embrapa BRS 1010IPRO, transgenic, with tolerance to the glyphosate herbicide and with the Intacta RR2 PROTM technology for caterpillar control. The size of the plots, the sowing dates, and the density of plants at each location are presented in Additional file 1: Table S4.
Plots and blocks were interspaced by 1 or $2 \mathrm{~m}$ corridors to avoid contamination of treatments.

The experimental design of the trials was randomized complete block design (RCBD), with six replications.

In the phenological stages V3-V5 (Fehr and Caviness 1977), foliar application of Co $\left(2.5 \mathrm{~g} \mathrm{ha}^{-1}\right)+\mathrm{Mo}$ $\left(20 \mathrm{~g} \mathrm{ha}^{-1}\right)$ was performed. No other micronutrients were applied. Approximately in R1 (Fehr and Caviness 1977), the T2 (non-inoculated control with $\mathrm{N}$-fertilizer), received the second dose of $\mathrm{N}$, of $100 \mathrm{~kg}$ of $\mathrm{N} \mathrm{ha}^{-1}$ as urea, side-dressed.

All cultural and phytosanitary treatments were carried out as specified in the technologies for soybean production (Embrapa Soja 2013).

\section{Plant sampling and analyses}

Between 42 and 49 days after sowing (DAS), corresponding to 35 to 36 days after emergence (DAE) (Additional file 1: Table S4), when the plants were in the V5 growth stage (Fehr and Caviness 1977), five plants were collected from each plot. Evaluations at this sampling included nodulation (number and dry weight), shoot dry weight, $\mathrm{N}$ content and total $\mathrm{N}$ accumulated in the shoot.

In the laboratory, shoots and the roots were separated, washed carefully and allowed to dry in an oven at $50{ }^{\circ} \mathrm{C}$, until they reached constant dry weight (approximately $72 \mathrm{~h}$ ). The nodules were removed from the roots, dried again and weighed to obtain nodule dry weight. The $\mathrm{N}$ content in shoot (N-Kjeldahl) was determined in a spectrophotometer by the salicylate green method, with reading at $697 \mathrm{~nm}$ (Feigl and Anger 1972). The N content multiplied by the biomass of the aerial part of the plants resulted in the $\mathrm{N}$ accumulated in shoots.

Grain yield was determined at the physiological maturation, harvesting the central area of each plot dates, ranging from 6.75 to $8 \mathrm{~m}^{2}$, as shown in Additional file 1: Table S4. The grains were cleaned, weighed and, after determining the moisture in a grain moisture determiner (Gehaka, model AGRI G800), the mass was corrected to $13 \%$ moisture. The $\mathrm{N}$ content in the grains was also determined (N-Kjeldahl) according to Feigl and Anger (1972). The $\mathrm{N}$ content multiplied by the grain dry weight resulted in the $\mathrm{N}$ accumulated in the grains.

\section{Statistical analysis}

The data from the experiments to analyze the use of different $\mathrm{C}$ sources and the time of inoculation were subjected to the test of normality and homogeneity of variances. Then, analysis of variance (ANOVA) was performed. When the " $F$ " test was significant at $5 \%$, the treatment meanswere compared by the Tukey test at $5 \%$, using the statistical program $R$. 
The data from each field trial were initially submitted to the test of normality of variables and homogeneity of variances. Then, analysis of variance (ANOVA) was carried out according to a randomized block design using the software Statistica version 7.0. When the "F" test was significant at $5 \%$, the treatment means were compared by the Duncan test, at the $5 \%$ level of significance. When the " $F$ " test was not significant at $5 \%$, the significance was verified at $10 \%$, as specified in Brazilian legislation for agronomic efficiency tests for the registration of inoculants (MAPA 2011), to compare the means at the level of $10 \%$ of significance. At the end, a joint analysis of the five trials was also carried out, using the same statistical tests.

\section{Results}

\section{Development of the co-inoculant formulation}

In the first stage of the study, as the inoculants produced in Brazil for the soybean crop contain two strains of Bradyrhizobium, mostly B. japonicum SEMIA 5079 and B. diazoefficiens SEMIA 5080, and two strains of A. brasilense, $\mathrm{Ab}-\mathrm{V} 5$ and $\mathrm{Ab}-\mathrm{V} 6$, the capacity to metabolize $\mathrm{C}$ sources was evaluated for each pair of strains. The genera differed in their ability to use $\mathrm{C}$ sources. For Bradyrhizobium, higher cell concentrations were achieved in the presence of sucrose, mannitol and glycerol (Table 2). For these sources, in the evaluation performed at 34 days, alkalinization of the culture medium formulated with organic acids was detected, varying from $\mathrm{pH} 8.17$ to
9.27, with less variation with mannitol, sucrose and yeast extract (data not shown).

For Azospirillum, the best growth was obtained with maleic acid and malic acid, but adequate cell concentrations were also obtained with sucrose, yeast extract and mannitol (Table 3). In general, there was alkalinization of the culture medium, varying from $\mathrm{pH} 8.05$ for yeast extract, to 8.79 with maleic acid, and the only exception was glycerol, with lower pH 7.01 (data not shown).

Based on the results obtained, formulations were evaluated (Table 1) to verify the growth capacity of Bradyrhizobium and Azospirillum, separately (data not shown). From the results obtained, six formulations were developed, which were evaluated for co-cultivation of Bradyrhizobium and Azospirillum for 30 days (Fig. 1). The results obtained indicated that it was possible to develop formulations that allow the co-cultivation of the two microorganisms. A formulation composed of malic acid, mannitol, yeast extract, $\mathrm{CaCl}_{2} \cdot 2 \mathrm{H}_{2} \mathrm{O}$, $\mathrm{K}_{2} \mathrm{HPO}, \mathrm{Mg} \mathrm{SO}_{4} \cdot 7 \mathrm{H}_{2} \mathrm{O}$ and $\mathrm{NH}_{4} \mathrm{NO}_{3}$ was then developed. Optionally, to allow higher cellular concentration, a micronutrient solution containing $\mathrm{CuSO}_{4} .5 \mathrm{H}_{2} \mathrm{O}$, $\mathrm{ZnSO}_{4} \cdot 7 \mathrm{H}_{2} \mathrm{O}, \mathrm{H}_{3} \mathrm{BO}_{3}, \mathrm{MnSO}_{4} \cdot \mathrm{H}_{2} \mathrm{O}$ e $\mathrm{NaMoO}_{4} \cdot 2 \mathrm{H}_{2} \mathrm{O}$ can be added. The concentrations of each component in the formulation are subject to industrial registration.

The growth curves of Bradyrhizobium and Azospirillum differ considerably, with slow growth of the first and fast growth of the second. Therefore, in order to find a balance, it is necessary to adjust the inoculation

Table 2 Cell concentration (UFC $\mathrm{mL}^{-1}$ ) of Bradyrhizobium spp. strains SEMIA 5079 and SEMIA 5080 growing with different carbon sources for 34 days

\begin{tabular}{|c|c|c|c|c|c|c|c|c|c|}
\hline \multirow[t]{2}{*}{ Days } & \multicolumn{9}{|c|}{ Carbon source } \\
\hline & Control & Yeast extract & Sucrose & Glycerol & Mannitol & Glutamic acid & Malic acid & Citric acid & Maleic acid \\
\hline 2 & $1.21 \times 10^{8}$ & $6.44 \times 10^{8}$ & $7.66 \times 10^{8}$ & $7.88 \times 10^{8}$ & $1.02 \times 10^{9}$ & $3.22 \times 10^{8}$ & $9.43 \times 10^{8}$ & $1.07 \times 10^{8}$ & $3.55 \times 10^{8}$ \\
\hline 3 & $3.10 \times 10^{8}$ & $9.10 \times 10^{8}$ & $1.69 \times 10^{9}$ & $1.04 \times 10^{9}$ & $9.29 \times 10^{8}$ & $1.99 \times 10^{8}$ & $4.22 \times 10^{8}$ & $1.66 \times 10^{8}$ & $8.75 \times 10^{7}$ \\
\hline 4 & $1.01 \times 10^{8}$ & $3.22 \times 10^{8}$ & $1.78 \times 10^{9}$ & $1.41 \times 10^{9}$ & $1.27 \times 10^{9}$ & $4.22 \times 10^{8}$ & $3.55 \times 10^{8}$ & $1.11 \times 10^{8}$ & $8.77 \times 10^{7}$ \\
\hline 5 & $1.13 \times 10^{8}$ & $9.32 \times 10^{8}$ & $2.44 \times 10^{9}$ & $1.18 \times 10^{9}$ & $1.22 \times 10^{9}$ & $3.88 \times 10^{8}$ & $4.55 \times 10^{8}$ & $9.64 \times 10^{7}$ & $6.66 \times 10^{7}$ \\
\hline 6 & $1.03 \times 10^{8}$ & $6.88 \times 10^{8}$ & $1.78 \times 10^{9}$ & $1.01 \times 10^{9}$ & $1.08 \times 10^{9}$ & $5.44 \times 10^{8}$ & $3.66 \times 10^{8}$ & $7.33 \times 10^{7}$ & $5.11 \times 10^{7}$ \\
\hline 7 & $1.95 \times 10^{8}$ & $4.77 \times 10^{8}$ & $1.81 \times 10^{9}$ & $1.08 \times 10^{9}$ & $9.74 \times 10^{8}$ & $5.33 \times 10^{8}$ & $3.33 \times 10^{8}$ & $7.88 \times 10^{7}$ & $3.77 \times 10^{7}$ \\
\hline 9 & $3.12 \times 10^{7}$ & $5.27 \times 10^{8}$ & $1.71 \times 10^{9}$ & $1.05 \times 10^{9}$ & $1.03 \times 10^{9}$ & $8.09 \times 10^{8}$ & $3.04 \times 10^{8}$ & $6.58 \times 10^{7}$ & $2.89 \times 10^{7}$ \\
\hline 10 & $-^{\mathrm{a}}$ & $7.10 \times 10^{8}$ & $1.77 \times 10^{9}$ & $1.33 \times 10^{9}$ & $1.08 \times 10^{9}$ & $1.06 \times 10^{9}$ & $2.77 \times 10^{8}$ & $6.22 \times 10^{7}$ & $2.11 \times 10^{7}$ \\
\hline 11 & - & $8.76 \times 10^{8}$ & $2.10 \times 10^{9}$ & $1.53 \times 10^{9}$ & $1.76 \times 10^{9}$ & $1.38 \times 10^{9}$ & $1.55 \times 10^{8}$ & $5.66 \times 10^{7}$ & $2.22 \times 10^{7}$ \\
\hline 12 & - & $7.44 \times 10^{8}$ & $2.01 \times 10^{9}$ & $1.18 \times 10^{9}$ & $1.03 \times 10^{9}$ & $1.17 \times 10^{9}$ & $4.55 \times 10^{7}$ & $5.55 \times 10^{7}$ & $1.99 \times 10^{7}$ \\
\hline 13 & - & $7.77 \times 10^{8}$ & $3.33 \times 10^{9}$ & $1.27 \times 10^{9}$ & $1.03 \times 10^{9}$ & $1.08 \times 10^{9}$ & $2.55 \times 10^{7}$ & $3.32 \times 10^{7}$ & $1.22 \times 10^{7}$ \\
\hline 20 & - & $4.77 \times 10^{8}$ & $2.44 \times 10^{9}$ & $1.29 \times 10^{8}$ & $8.77 \times 10^{8}$ & $2.66 \times 10^{8}$ & - & $9.98 \times 10^{6}$ & $3.44 \times 10^{6}$ \\
\hline 23 & - & $6.88 \times 10^{8}$ & $2.04 \times 10^{9}$ & $1.36 \times 10^{9}$ & $1.07 \times 10^{9}$ & $1.20 \times 10^{8}$ & - & - & - \\
\hline 25 & - & $5.55 \times 10^{8}$ & $1.54 \times 10^{9}$ & $1.25 \times 10^{9}$ & $1.18 \times 10^{9}$ & $6.22 \times 10^{7}$ & - & - & - \\
\hline 27 & - & $6.11 \times 10^{8}$ & $1.41 \times 10^{9}$ & $1.14 \times 10^{9}$ & $1.11 \times 10^{9}$ & $2.99 \times 10^{7}$ & - & - & - \\
\hline 34 & - & $3.33 \times 10^{8}$ & $1.26 \times 10^{9}$ & $5.88 \times 10^{8}$ & $8.55 \times 10^{8}$ & $4.44 \times 10^{6}$ & - & - & - \\
\hline
\end{tabular}

${ }^{\mathrm{a}}$ Traces indicate absence of growth 
Table 3 Cell concentration (UFC $\mathrm{mL}^{-1}$ ) of Azospirillum brasilense strains Ab-V5 e Ab-V6 growing with different carbon sources for 34 days

\begin{tabular}{|c|c|c|c|c|c|c|c|c|c|}
\hline \multirow[t]{2}{*}{ Days } & \multicolumn{9}{|c|}{ Carbon source } \\
\hline & Control & Yeast extract & Sucrose & Glycerol & Mannitol & Glutamic acid & Malic acid & Citric acid & Maleic acid \\
\hline 1 & $3.99 \times 10^{7}$ & $6.88 \times 10^{8}$ & $6.99 \times 10^{8}$ & $8.66 \times 10^{8}$ & $5.33 \times 10^{8}$ & $1.63 \times 10^{9}$ & $6.55 \times 10^{8}$ & $5.11 \times 10^{8}$ & $6.44 \times 10^{8}$ \\
\hline 2 & $5.30 \times 10^{7}$ & $4.55 \times 10^{8}$ & $4.10 \times 10^{8}$ & $1.11 \times 10^{8}$ & $5.88 \times 10^{8}$ & $1.58 \times 10^{9}$ & $5.66 \times 10^{8}$ & $1.48 \times 10^{8}$ & $6.11 \times 10^{8}$ \\
\hline 3 & $7.88 \times 10^{7}$ & $4.10 \times 10^{8}$ & $3.33 \times 10^{8}$ & $9.98 \times 10^{7}$ & $4.21 \times 10^{8}$ & $1.70 \times 10^{9}$ & $2.77 \times 10^{8}$ & $1.07 \times 10^{8}$ & $5.11 \times 10^{8}$ \\
\hline 6 & $2.22 \times 10^{7}$ & $2.44 \times 10^{8}$ & $1.18 \times 10^{8}$ & $6.75 \times 10^{7}$ & $4.22 \times 10^{8}$ & $7.66 \times 10^{8}$ & $1.41 \times 10^{8}$ & $4.85 \times 10^{6}$ & $4.33 \times 10^{8}$ \\
\hline 7 & $6.55 \times 10^{6}$ & $2.99 \times 10^{8}$ & $1.02 \times 10^{8}$ & $7.76 \times 10^{7}$ & $1.65 \times 10^{8}$ & $9.86 \times 10^{8}$ & $9.75 \times 10^{7}$ & - & $4.77 \times 10^{8}$ \\
\hline 9 & $-^{\mathrm{a}}$ & $4.77 \times 10^{7}$ & $1.01 \times 10^{8}$ & $6.66 \times 10^{6}$ & $3.79 \times 10^{7}$ & $5.12 \times 10^{7}$ & $8.21 \times 10^{7}$ & - & $2.33 \times 10^{8}$ \\
\hline 10 & - & $4.77 \times 10^{7}$ & $9.39 \times 10^{7}$ & - & $4.21 \times 10^{7}$ & $8.55 \times 10^{7}$ & $5.69 \times 10^{7}$ & - & $2.99 \times 10^{8}$ \\
\hline 13 & - & $2.77 \times 10^{7}$ & $9.63 \times 10^{7}$ & - & $2.77 \times 10^{7}$ & $4.44 \times 10^{6}$ & $3.33 \times 10^{8}$ & - & $1.55 \times 10^{8}$ \\
\hline 14 & - & $3.77 \times 10^{7}$ & $7.70 \times 10^{7}$ & - & $1.95 \times 10^{7}$ & $5.66 \times 10^{6}$ & $8.43 \times 10^{7}$ & - & $1.36 \times 10^{8}$ \\
\hline 15 & - & $3.22 \times 10^{7}$ & $9.98 \times 10^{7}$ & - & $2.44 \times 10^{7}$ & $4.44 \times 10^{6}$ & $1.01 \times 10^{8}$ & - & $1.65 \times 10^{8}$ \\
\hline 18 & - & $5.00 \times 10^{7}$ & $1.07 \times 10^{8}$ & - & $1.44 \times 10^{7}$ & - & $4.55 \times 10^{7}$ & - & $1.39 \times 10^{8}$ \\
\hline 21 & - & $2.77 \times 10^{7}$ & $6.66 \times 10^{7}$ & - & $1.77 \times 10^{7}$ & - & $9.21 \times 10^{7}$ & - & $4.44 \times 10^{7}$ \\
\hline 22 & - & $3.33 \times 10^{7}$ & $8.44 \times 10^{7}$ & - & $2.99 \times 10^{7}$ & - & $1.03 \times 10^{8}$ & - & $1.04 \times 10^{8}$ \\
\hline 23 & - & $3.11 \times 10^{7}$ & $9.63 \times 10^{7}$ & - & $2.66 \times 10^{7}$ & - & $9.10 \times 10^{7}$ & - & $1.05 \times 10^{8}$ \\
\hline 27 & - & $2.33 \times 10^{7}$ & $4.77 \times 10^{7}$ & - & $1.77 \times 10^{7}$ & - & $7.22 \times 10^{7}$ & - & $4.88 \times 10^{7}$ \\
\hline 28 & - & $1.99 \times 10^{7}$ & $5.88 \times 10^{7}$ & - & $2.77 \times 10^{7}$ & - & $3.77 \times 10^{7}$ & - & $6.66 \times 10^{7}$ \\
\hline 30 & - & $2.22 \times 10^{7}$ & $4.66 \times 10^{7}$ & - & $2.66 \times 10^{7}$ & - & $5.22 \times 10^{7}$ & - & $3.88 \times 10^{7}$ \\
\hline 31 & - & $3.22 \times 10^{7}$ & $5.44 \times 10^{7}$ & - & $1.77 \times 10^{7}$ & - & $6.66 \times 10^{7}$ & - & $4.22 \times 10^{7}$ \\
\hline 34 & - & $2.88 \times 10^{7}$ & $4.55 \times 10^{7}$ & - & $1.66 \times 10^{7}$ & - & $6.11 \times 10^{7}$ & - & $6.55 \times 10^{7}$ \\
\hline
\end{tabular}

${ }^{\mathrm{a}}$ Traces indicate absence of growth

time. In the test performed with different times of inoculation of Azospirillum in the formulation developed, the best results were obtained when Azospirillum was inoculated on the third day of growth of Bradyrhizobium (Table 4).

\section{Field trials to evaluate agronomic efficiency Characterization of the areas}

The sites where the five experiments were performed represent distinct edaphoclimatic conditions of soybeanproducing areas in Brazil. Regarding the main characteristics of the soils, the granulometry varied from highly clayey soils, in Londrina, with $75.2 \%$ clay in the $0-20 \mathrm{~cm}$ layer, to highly sandy soils, in Paranavaí, with $90.6 \%$ sand in the 0-20 cm layer (Additional file 1: Table S3). In general, Ca levels were low, but $\mathrm{P}$ levels ranged from low (Lutécia) to high (Londrina); Mn contents were high in all soils, except in Ponta Grossa (Additional file 1: Table S2).

Two areas were cropped for the first time and had never received inoculants before, and therefore showed low population of rhizobia compatible with soybean (Paranavaí and Lutécia), while the other areas had been previously cultivated and inoculated, harboring high populations, above $1.47 \times 10^{4}$ rhizobia $^{-1}$ of soil (Additional file 1: Table S2).
All areas had high populations of diazotrophic bacteria, estimated to be at least $1.10 \times 10^{3}$ bacteria $^{-1}$ soil (Additional file 1: Table S3).

\section{Field trials performed in areas without history of inoculation}

In Lutécia (SP), in the evaluation carried out at the V5 stage, there was no nodulation in the non-inoculated treatments without (T1) and with (T2) N-fertilizer (Table 5). The composite inoculant developed in this study (T6) resulted in number of nodules comparable to those provided by the peat inoculant (T3) and by the commercial co-inoculation, represented by the separate supply of Bradyrhizobium spp. and A. brasilense (T5) and higher than the commercial liquid inoculant containing only Bradyrhizobium spp. (T4). Nodule dry weight of the $\mathrm{T} 6$ treatment was also comparable to $\mathrm{T} 5$, although lower than T3. Still at V5, the best performance of shoot dry weight and total $\mathrm{N}$ accumulated in shoots was verified in the treatment receiving $\mathrm{N}$-fertilizer. At physiological maturity, the highest yields obtained in Lutécia were found with the peat inoculant (T3), commercial co-inoculation (T5), and the composite inoculant developed in this study (T6). Grain yield of the composite inoculant developed in this study exceeded the treatment receiving $\mathrm{N}$-fertilizer by $26 \%$. The two co-inoculants were the 


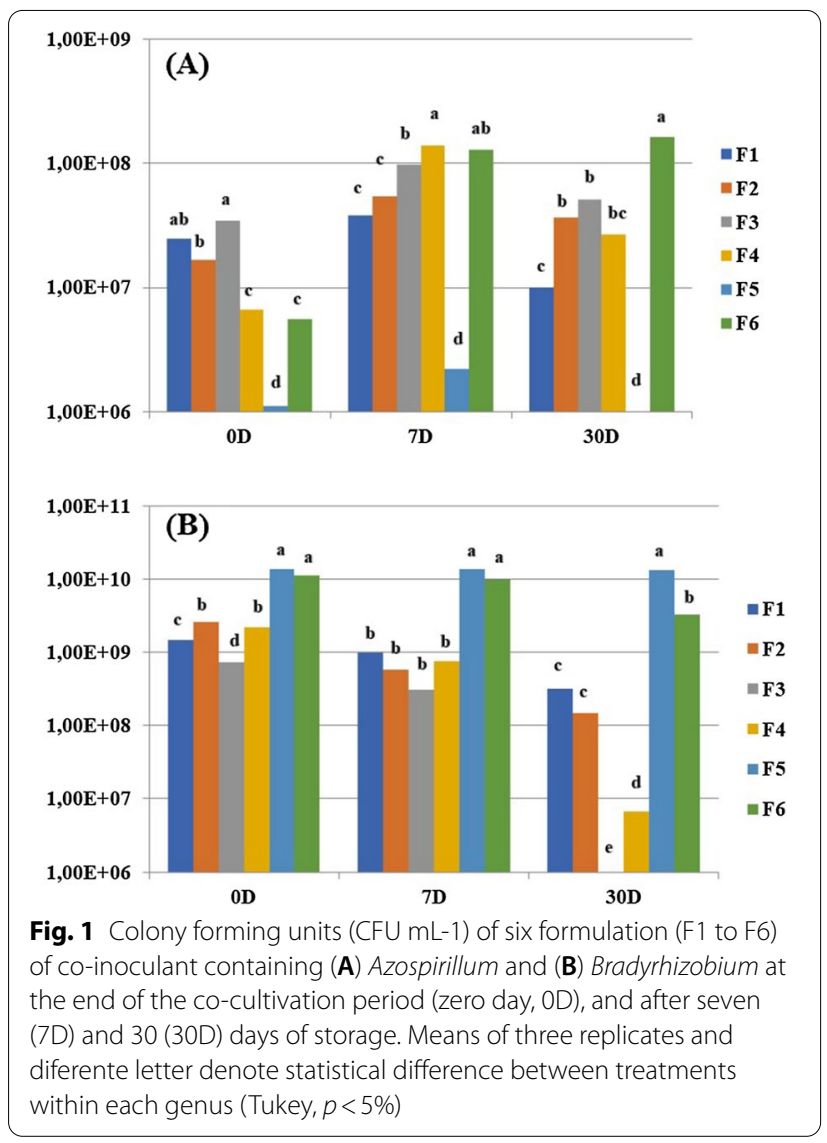

treatments that resulted in a greater mass of 100 grains. All inoculated treatments resulted in higher content and total $\mathrm{N}$ accumulated in the grains, statistically superior to the non-inoculated treatments receiving (T2) or not (T1) $\mathrm{N}$-fertilizer (Table 5).

In the other area cropped with soybean for the first time, in Paranavaí (PR), as expected, nodulation was practically absent in the non-inoculated plants, with or without $\mathrm{N}$-fertilizer, in the evaluation carried out at V5
(Table 5). All inoculated treatments resulted in increases in nodule number and dry weight. Still at V5, the two co-inoculated treatments (T5 and T6) did not differ statistically from the treatment receiving $\mathrm{N}$-fertilizer (T2), with higher values of shoot dry weight. All inoculated treatments increased the $\mathrm{N}$ content in shoots in comparison to the two non-inoculated controls (T1 and T2). In relation to the total $\mathrm{N}$ accumulated in shoots, $\mathrm{T} 1$ only differed statistically from the non-inoculated treatment receiving $\mathrm{N}$-fertilizer (T2). At physiological maturity, the highest yield was obtained with the composite inoculant developed in this study, which did not differ statistically from the commercial co-inoculation with the two species applied separately. Both treatments of co-inoculation, T5 and $\mathrm{T} 6$ resulted in statistical difference in relation to the non-inoculated controls, with and without $\mathrm{N}$-fertilizer, with the composite inoculant developed in this study (T6) being superior to the treatment receiving $\mathrm{N}$-fertilizer by $36 \%$. The grain yield of the treatment receiving the composite inoculant differed statistically from the single inoculation with Bradyrhizobium in liquid or peat formulation. As in Lutécia, all inoculated treatments resulted in higher contents and total $\mathrm{N}$ accumulated in grains in comparison to the non-inoculated controls without (T1) and with (T2) N-fertilizer (Table 5).

\section{Field trials performed in previously inoculated areas} In Florestópolis (PR), with a naturalized population estimated at $2.15 \times 10^{5}$ rhizobia $\mathrm{g}^{-1}$ of soil (Additional file 1: Table S3), plants nodulated well, even in the noninoculated controls, with no statistical differences in V5 (Table 6). Also, at V5 stage the highest shoot dry weight and total $\mathrm{N}$ accumulated in shoots were found in the non-inoculated treatments receiving $\mathrm{N}$-fertilizer (T2), in the commercial liquid inoculant with Bradyrhizobium (T4) and in the composite inoculant developed in this study (T6). The composite inoculant resulted in the highest grain yield, statistically similar to the commercial

Table 4 Effect of different times of inoculation of Azospirillum on the growth (log of CFU) of Bradyrhizobium and Azospirillum co-cultivated in the same culture medium

\begin{tabular}{|c|c|c|c|c|c|c|c|c|}
\hline \multirow[t]{4}{*}{ Days of growth } & \multicolumn{4}{|c|}{ Bradyrhizobium } & \multicolumn{4}{|c|}{ Azospirillum } \\
\hline & \multirow{3}{*}{$\begin{array}{l}\text { Single } \\
\text { Control }\end{array}$} & \multirow{2}{*}{\multicolumn{3}{|c|}{$\frac{\text { Composite inoculant }}{\text { Time of inoculation }^{a}}$}} & \multirow{3}{*}{$\begin{array}{l}\text { Single } \\
\text { Control }\end{array}$} & \multirow{2}{*}{\multicolumn{3}{|c|}{$\frac{\text { Composite inoculant }}{\text { Time of inoculation }^{a}}$}} \\
\hline & & & & & & & & \\
\hline & & $\mathrm{T} 1$ & $\mathrm{~T} 2$ & T3 & & $\mathrm{T} 1$ & $\mathrm{~T} 2$ & T3 \\
\hline 2 & $9.34 b$ & & & & 8.00 & & & \\
\hline 3 & $9.69 a b$ & $9.16 \mathrm{c}$ & & & 8.11 & $8.00 \mathrm{a}$ & & \\
\hline 4 & $9.69 a b$ & $9.19 b c$ & $9.01 \mathrm{c}$ & & 8.23 & $7.99 a$ & $8.11 \mathrm{a}$ & \\
\hline 5 & $10.14 \mathrm{a}$ & $9.13 c$ & $9.67 a b$ & $9.17 c$ & 8.47 & $7.82 \mathrm{a}$ & $8.33 a$ & $8.15 \mathrm{a}$ \\
\hline
\end{tabular}

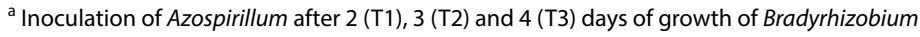


Table 5 Parameters evaluated in soybean cultivar BRS 1010IPRO with different treatments of inoculation with Bradyrhizobium and co-inoculation with Bradyrhizobium and Azospirillum in field trials performed in first-year cropping areas, without naturalized population of compatible soybean bradyrhizobia, in Lutécia-SP e Paranavaí-PR, Brazil

\begin{tabular}{|c|c|c|c|c|c|c|c|c|c|}
\hline \multirow[t]{3}{*}{ Treatment $^{\mathrm{a}}$} & \multicolumn{5}{|l|}{ Stage V5 } & \multicolumn{4}{|c|}{ Physiological maturity } \\
\hline & \multicolumn{2}{|l|}{ Nodulation } & \multirow{2}{*}{$\begin{array}{l}\text { Shoot dry } \\
\text { weight } \\
\text { g plant }^{-1}\end{array}$} & \multicolumn{2}{|l|}{$\mathrm{N}$ in shoot } & \multicolumn{2}{|l|}{$\mathrm{N}$ in grain } & \multirow{2}{*}{$\begin{array}{l}\text { Grain yield } \\
\mathrm{kg} \mathrm{ha}^{-1}\end{array}$} & \multirow{2}{*}{$\begin{array}{l}\text { Mass of } 100 \\
\text { grains } \\
\mathrm{g}\end{array}$} \\
\hline & $\mathrm{n}^{\circ}$ plant $^{-1}$ & mg plant $^{-1}$ & & $\begin{array}{l}\text { Content g } \\
\mathbf{k g}^{-1}\end{array}$ & $\begin{array}{l}\text { Total mg } \\
\text { plant }^{-1}\end{array}$ & $\begin{array}{l}\text { Content g } \\
\mathbf{k g}^{-1}\end{array}$ & $\begin{array}{l}\text { Total kg } \\
\mathrm{ha}^{-1}\end{array}$ & & \\
\hline \multicolumn{10}{|l|}{ Lutécia (SP) } \\
\hline T1-Control-N & $0.0 b^{b}$ & $0.0 c$ & $6.71 \mathrm{~b}$ & $21.0^{\text {n.s.b }}$ & $140.9 b$ & $38.3 c$ & $61 c$ & $1601 c$ & $14.4 d$ \\
\hline $\begin{array}{l}\text { T2-Con- } \\
\text { trol + } 200 \mathrm{~kg} \mathrm{~N}\end{array}$ & $0.0 \mathrm{~b}$ & $0.0 \mathrm{c}$ & $9.53 \mathrm{a}$ & 23.9 & $227.7 \mathrm{a}$ & $43.8 \mathrm{~b}$ & $142 b$ & $3244 b$ & $15.7 c$ \\
\hline T3-Peat Brady & $12.5 \mathrm{a}$ & $54.7 \mathrm{a}$ & $4.73 b$ & 25.3 & $119.7 b$ & $52.9 \mathrm{a}$ & $215 a$ & 4059 a & $17.2 \mathrm{~b}$ \\
\hline T4-Liquid Brady & $4.9 b$ & $30.5 b$ & $4.70 \mathrm{~b}$ & 22.0 & $103.4 b$ & $51.6 \mathrm{a}$ & $181 \mathrm{a}$ & $3500 \mathrm{~b}$ & $15.5 c$ \\
\hline $\begin{array}{l}\text { T5-Single } \\
\text { Brady + Single } \\
\text { Azo (trade- } \\
\text { mark) }\end{array}$ & $10.6 \mathrm{a}$ & $30.3 b$ & $5.71 \mathrm{~b}$ & 21.0 & $119.9 b$ & $51.7 \mathrm{a}$ & $211 a$ & $4086 \mathrm{a}$ & $18.0 \mathrm{a}$ \\
\hline $\begin{array}{l}\text { T6_-Composite } \\
\text { inoculant } \\
\text { Brady+Azo }\end{array}$ & $10.5 \mathrm{a}$ & $33.8 \mathrm{~b}$ & $6.02 b$ & 25.8 & $155.3 b$ & $50.7 \mathrm{a}$ & $208 \mathrm{a}$ & $4100 \mathrm{a}$ & $17.7 \mathrm{ab}$ \\
\hline$p$ value & 0.001 & 0.001 & 0.019 & 0.10 & 0.009 & 0.001 & 0.001 & 0.001 & 0.001 \\
\hline \multicolumn{10}{|l|}{ Paranavaí (PR) } \\
\hline $\mathrm{T} 1-$ Control- $\mathrm{N}$ & $0.1 b$ & $0.5 b$ & $3.00 \mathrm{~b}$ & $17.1 \mathrm{~b}$ & $51.3 b$ & $50.0 \mathrm{~b}$ & $110 \mathrm{~b}$ & $2202 d$ & $12.6 \mathrm{a}$ \\
\hline $\begin{array}{l}\text { T2-Con- } \\
\text { trol + } 200 \mathrm{~kg} \mathrm{~N}\end{array}$ & $0.1 \mathrm{~b}$ & $0.8 \mathrm{~b}$ & $5.34 \mathrm{a}$ & $17.8 \mathrm{~b}$ & $95.0 \mathrm{a}$ & $41.7 c$ & $107 b$ & $2574 \mathrm{~cd}$ & $12.8 \mathrm{a}$ \\
\hline T3_Peat Brady & $13.2 \mathrm{a}$ & $101.0 \mathrm{a}$ & $3.62 b$ & $22.1 \mathrm{a}$ & $80.0 \mathrm{ab}$ & $54.0 \mathrm{a}$ & $157 a$ & $2904 b c$ & $11.8 \mathrm{~b}$ \\
\hline T4-Liquid Brady & $8.5 \mathrm{a}$ & $74.2 \mathrm{a}$ & $3.60 \mathrm{~b}$ & $21.0 \mathrm{a}$ & $75.6 \mathrm{ab}$ & $51.0 \mathrm{ab}$ & $143 a$ & $2800 \mathrm{bc}$ & $11.5 b$ \\
\hline $\begin{array}{l}\text { T5_-Single } \\
\text { Brady+ Single } \\
\text { Azo (trade- } \\
\text { mark) }\end{array}$ & $10.7 \mathrm{a}$ & $76.2 \mathrm{a}$ & $4.32 \mathrm{ab}$ & $20.3 a$ & $87.7 \mathrm{ab}$ & 52.9 a & $166 a$ & $3140 a b$ & $12.5 \mathrm{a}$ \\
\hline $\begin{array}{l}\text { T6_Composite } \\
\text { inoculant } \\
\text { Brady+Azo }\end{array}$ & $8.6 \mathrm{a}$ & $77.6 \mathrm{a}$ & $3.92 \mathrm{ab}$ & $21.2 \mathrm{a}$ & $83.1 \mathrm{ab}$ & $52.0 \mathrm{a}$ & 181 a & $3491 \mathrm{a}$ & $12.4 \mathrm{a}$ \\
\hline$p$ value & 0.001 & 0.001 & 0.038 & 0.007 & 0.097 & 0.001 & 0.001 & 0.001 & 0.003 \\
\hline
\end{tabular}

${ }^{a}$ T3 e T4, peat and liquid inoculant with Bradyrhizobium spp. strains SEMIA 5079+SEMIA 5080, applied to supply $1.2 \times 10^{6}$ cells seed $^{-1}$; T5, T4+ liquid inoculant with A. brasilense strains Ab-V5 + Ab-V6 applied to supply $1.2 \times 10^{5}$ cells seed $^{-1}$; T6, composite inoculant developed in this study, with B. diazoefficiens strain SEMIA 5080 $\left(1.2 \times 10^{6}\right.$ cells seed $\left.^{-1}\right)$ and $A$. brasilense strain Ab-V6 $\left(1.2 \times 10^{5}\right.$ cells seed $\left.^{-1}\right)$

${ }^{\mathrm{b}}$ Data represent the means of six replicates and when followed by different letters, within each column, are statistically different (Duncan, $p<5 \%$ or $10 \%$; $\mathrm{n} . \mathrm{s}$., statistically non-significant)

co-inoculation with the isolated microorganisms. The composite inoculant developed in this study (T6) increased grain yield by $24 \%$ in comparison to the noninoculated treatment (T1). All inoculated treatments resulted in increases in the $\mathrm{N}$ content in the grains and, in the case of the total $\mathrm{N}$ accumulated in the grains, they were statistically similar to the treatment receiving $\mathrm{N}$-fertilizer (Table 6).

In Londrina, the population was estimated at $1.47 \times 10^{3}$ rhizobia $\mathrm{g}^{-1}$ of soil (Additional file 1: Table S3). No statistical differences were detected between treatments with or without inoculation in any of the parameters evaluated at V5, except for inhibition of nodulation by the application of $\mathrm{N}$-fertilizer (T2) (Table 6). There were also no differences between treatments in grain yield and other parameters evaluated at physiological maturity. In Londrina, an extra treatment was performed with the in-furrow application of three doses of the composite inoculant developed in this study, but there was also no statistical difference between this treatment and the others. The results indicate that the naturalized population of Bradyrhizobium in the soil was able to provide the $\mathrm{N}$ necessary for the development of the plants, which is confirmed by the 
Table 6 Parameters evaluated in soybean cultivar BRS 1010IPRO with different treatments of inoculation with Bradyrhizobium and co-inoculation with Bradyrhizobium and Azospirillum in field trials performed in areas traditionally cropped with soybean, showing naturalized population of soybean bradyrhizobia, in Florestópolis-PR, Londrina-PR and Ponta-Grossa-PR, Brazil

\begin{tabular}{|c|c|c|c|c|c|c|c|c|c|}
\hline \multirow[t]{3}{*}{ Treatment $^{\mathrm{a}}$} & \multicolumn{5}{|l|}{ Stage V5 } & \multicolumn{4}{|c|}{ Physiological maturity } \\
\hline & \multicolumn{2}{|l|}{ Nodulation } & \multirow{2}{*}{$\begin{array}{l}\text { Shoot dry } \\
\text { weight } \\
\text { g plant }^{-1}\end{array}$} & \multicolumn{2}{|l|}{$\mathrm{N}$ in shoot } & \multicolumn{2}{|l|}{$\mathrm{N}$ in grains } & \multirow{2}{*}{$\begin{array}{l}\text { Grain yield } \\
\mathrm{kg} \mathrm{ha}^{-1}\end{array}$} & \multirow{2}{*}{$\begin{array}{l}\text { Mass of } 100 \\
\text { grains } \\
\mathrm{g}\end{array}$} \\
\hline & $n^{\circ}$ plant $^{-1}$ & mg plant $^{-1}$ & & $\begin{array}{l}\text { Content } \mathbf{g} \\
\mathbf{k g}^{-1}\end{array}$ & $\begin{array}{l}\text { Total mg } \\
\text { plant }^{-1}\end{array}$ & $\begin{array}{l}\text { Content } \mathbf{g} \\
\mathbf{k g}^{-1}\end{array}$ & $\begin{array}{l}\text { Total kg } \\
\mathrm{ha}^{-1}\end{array}$ & & \\
\hline \multicolumn{10}{|l|}{ Florestópolis (PR) } \\
\hline $\mathrm{T} 1$-Control-N & $26.2^{\text {n.s.b }}$ & $64.3^{\mathrm{n} . \mathrm{s}}$ & $1.02 b^{b}$ & $29.6 a$ & $30.2 \mathrm{ab}$ & $45.4 \mathrm{C}$ & $124 b$ & $2722 b$ & $15.47^{\text {n.s }}$ \\
\hline $\begin{array}{l}\text { T2-Con- } \\
\text { trol + } 200 \mathrm{~kg} \mathrm{~N}\end{array}$ & 25.3 & 65.1 & $1.61 \mathrm{a}$ & $29.7 a$ & $47.8 \mathrm{a}$ & $46.6 \mathrm{~b}$ & $147 a b$ & $3158 a b$ & 15.90 \\
\hline T3_Peat Brady & 26.2 & 55.8 & $0.93 b$ & $28.5 \mathrm{ab}$ & $26.5 b$ & $48.3 \mathrm{ab}$ & $137 a b$ & $2833 a b$ & 15.33 \\
\hline T4_Liquid Brady & 25.4 & 66.0 & $1.28 \mathrm{ab}$ & $26.9 c$ & $34.4 \mathrm{ab}$ & $48.0 \mathrm{ab}$ & $131 \mathrm{ab}$ & $2725 b$ & 15.50 \\
\hline $\begin{array}{l}\text { T5_-Single } \\
\text { Brady + Single } \\
\text { Azo (trademark) }\end{array}$ & 26.8 & 62.9 & $0.98 b$ & $26.7 c$ & $26.2 b$ & 49.8 a & $165 a$ & $3321 \mathrm{ab}$ & 15.60 \\
\hline $\begin{array}{l}\text { T6-Composite } \\
\text { inoculant } \\
\text { Brady + Azo }\end{array}$ & 29.4 & 71.9 & $1.22 \mathrm{ab}$ & $26.2 c$ & $31.9 \mathrm{ab}$ & $49.0 \mathrm{a}$ & $165 a$ & 3368 a & 15.85 \\
\hline$p$ value & 0.10 & 0.10 & 0.095 & 0.02 & 0.090 & 0.001 & 0.095 & 0.090 & 0.10 \\
\hline \multicolumn{10}{|l|}{ Londrina (PR) } \\
\hline $\mathrm{T} 1$-Control-N & $56.9 \mathrm{a}$ & $207 a$ & $9.32^{n . s}$ & $27.4^{n . s}$ & $255^{n . s}$ & $44.9^{\text {n.s }}$ & $184^{\mathrm{n} . \mathrm{s}}$ & $4101^{\text {n.s }}$ & $17.3^{\text {n.s }}$ \\
\hline $\begin{array}{l}\text { T2-Con- } \\
\text { trol }+200 \mathrm{~kg} \mathrm{~N}\end{array}$ & $27.8 b$ & $85 b$ & 9.91 & 29.8 & 295 & 45.7 & 186 & 4067 & 17.7 \\
\hline T3—Peat Brady & $54.8 \mathrm{a}$ & $215 \mathrm{a}$ & 8.66 & 31.9 & 276 & 45.3 & 187 & 4137 & 17.3 \\
\hline T4-Liquid Brady & $55.0 \mathrm{a}$ & $210 a$ & 8.50 & 31.8 & 270 & 45.1 & 184 & 4080 & 17.1 \\
\hline $\begin{array}{l}\text { T5_-Single } \\
\text { Brady+ Single } \\
\text { Azo (trademark) }\end{array}$ & $55.6 \mathrm{a}$ & $215 a$ & 9.20 & 32.4 & 298 & 44.5 & 186 & 4193 & 17.0 \\
\hline $\begin{array}{l}\text { T6_Composite } \\
\text { inoculant } \\
\text { Brady + Azo }\end{array}$ & $46.3 \mathrm{a}$ & $188 a$ & 8.56 & 31.0 & 265 & 44.8 & 184 & 4112 & 17.2 \\
\hline $\begin{array}{l}\text { T7-T6 applied } \\
\text { in-furrow }\end{array}$ & $48.2 \mathrm{a}$ & $177 a$ & 8.63 & 30.9 & 267 & 44.0 & 187 & 4260 & 17.1 \\
\hline$p$ value & 0.007 & 0.001 & 0.10 & 0.10 & 0.10 & 0.10 & 0.10 & 0.10 & 0.10 \\
\hline \multicolumn{10}{|l|}{ Ponta Grossa (PR) } \\
\hline T1-Control-N & $20.4 b$ & $65.0 \mathrm{~b}$ & $4.55 b$ & $38.4 b$ & $174 c$ & $44.1 \mathrm{~b}$ & $176 b$ & $4001 \mathrm{~b}$ & $16.6^{\mathrm{n} . \mathrm{s}}$ \\
\hline $\begin{array}{l}\text { T2-Con- } \\
\text { trol + } 200 \mathrm{~kg} \\
\text { de N }\end{array}$ & $20.8 b$ & $32.9 c$ & $6.75 a$ & $42.3 a b$ & $286 a$ & $43.7 b$ & $177 b$ & $4048 \mathrm{~b}$ & 16.7 \\
\hline T3_Peat Brady & $21.0 \mathrm{~b}$ & $67.9 \mathrm{~b}$ & $4.58 b$ & $38.8 b$ & $177 c$ & $45.8 \mathrm{ab}$ & $184 b$ & $4025 b$ & 16.0 \\
\hline T4_Liquid Brady & $20.2 b$ & $66.0 \mathrm{~b}$ & $4.33 b$ & $38.9 b$ & $168 c$ & $46.0 \mathrm{ab}$ & $185 b$ & $4020 \mathrm{~b}$ & 16.1 \\
\hline $\begin{array}{l}\text { T5-Single } \\
\text { Brady + Single } \\
\text { Azo (trademark) }\end{array}$ & $28.9 \mathrm{ab}$ & $85.0 \mathrm{a}$ & $5.40 \mathrm{ab}$ & $42.0 \mathrm{ab}$ & $218 b$ & 48.9 a & $212 a$ & $4335 \mathrm{ab}$ & 16.5 \\
\hline $\begin{array}{l}\text { T6_Composite } \\
\text { inoculant } \\
\text { Brady +Azo }\end{array}$ & $26.3 a b$ & $85.8 \mathrm{a}$ & $5.44 a b$ & $45.7 a$ & $249 a b$ & $48.7 \mathrm{a}$ & $222 \mathrm{a}$ & $4566 a$ & 16.9 \\
\hline $\begin{array}{l}\text { T7-T6 applied } \\
\text { in-furrow }\end{array}$ & $31.4 \mathrm{a}$ & $94.8 \mathrm{a}$ & $5.42 a b$ & $46.6 \mathrm{a}$ & $252 a b$ & $48.0 \mathrm{a}$ & $221 \mathrm{a}$ & $4528 \mathrm{a}$ & 16.7 \\
\hline$p$ value & 0.092 & 0.003 & 0.04 & 0.090 & 0.02 & 0.02 & 0.095 & 0.087 & 0.10 \\
\hline
\end{tabular}

${ }^{a}$ T3 e T4, peat and liquid inoculant with Bradyrhizobium spp. strains SEMIA 5079+SEMIA 5080, applied to supply $1.2 \times 10^{6}$ cells seed $^{-1}$; T5, T4+ liquid inoculant with A. brasilense strains Ab-V5 $+\mathrm{Ab}-\mathrm{V} 6$ applied to supply $1.2 \times 10^{5}$ cells seed $^{-1} ; \mathrm{T} 6$, composite inoculant developed in this study, with B. diazoefficiens strain SEMIA 5080 $\left(1.2 \times 10^{6}\right.$ cells seed $\left.^{-1}\right)$ and $A$. brasilense strain Ab-V6 $\left(1.2 \times 10^{5}\right.$ cells seed $\left.^{-1}\right) ; \mathrm{T}$, treatment T6 applied in-furrow, 3 doses

${ }^{\mathrm{b}}$ Data represent the means of six replicates and when followed by different letters, within each column, are statistically different (Duncan, $p<5 \%$ or $10 \%$; n.s., statistically non-significant 
finding that there was no benefit from the application of N-fertilizer (Table 6).

In Ponta Grossa, the treatment with the composite inoculant developed applied in-furrow (T7) was also added and the three treatments with co-inoculation (T5, T6 and T7) resulted in the highest values of nodule number and dry weight at V5 (Table 5). Regarding nodule dry weight, there was inhibition by the application of $\mathrm{N}$-fertilizer. In the same harvest, the two treatments with the composite inoculant developed in this study, T6 and $\mathrm{T} 7$, showed the best performance of $\mathrm{N}$ content and total $\mathrm{N}$ accumulated in shoots, not differing statistically from the $\mathrm{N}$-fertilizer. At the physiological maturity, the highest yields were obtained with the composite inoculant developed in this study, applied on seeds (T6) or in-furrow (T7), not differing statistically from the commercial coinoculation with the two separate bacteria (T5) and from the non-inoculated treatment with $\mathrm{N}$-fertilizer (T2). The composite inoculant developed in this study resulted in statistically significant increase in grain yield, in relation to the non-inoculated control (T1), of $565 \mathrm{~kg} \mathrm{ha}^{-1}$ and $527 \mathrm{~kg} \mathrm{ha}^{-1}$ when applied on seeds (T6) or in-furrow (T7), respectively. The developed composite inoculant also statistically increased grain yield in relation to the non-inoculated control receiving $\mathrm{N}$-fertilizer (T2), the peat inoculant (T3) and the liquid inoculant (T4) containing only Bradyrhizobium spp. It should also be noted the higher values of total $\mathrm{N}$ accumulated in the grains obtained in all co-inoculated treatments and the increase in the $\mathrm{N}$ content in the grains in all inoculated treatments (Table 5).

In a joint analysis of the five trials, considering the average grain yield, the composite inoculant developed in this study was statistically superior to the non-inoculated controls without and with $\mathrm{N}$-fertilizer and to the commercial liquid inoculant containing only Bradyrhizobium, and equal to the commercial co-inoculation with the bacteria used separately (Fig. 2). Similar results were obtained in the joint analysis of the total $\mathrm{N}$ accumulated in grains, with the composite inoculant resulting in statistically significant increases of 27,40 and $61 \mathrm{~kg}$ of N in grains $\mathrm{ha}^{-1}$ in comparison to the liquid inoculant carrying only Bradyrhizobium spp. and to the non-inoculated controls with and without $\mathrm{N}$-fertilizer, respectively (Fig. 2).

\section{Discussion}

Although sucrose, mannitol, and glycerol were the C sources that yielded higher cell concentrations, growth of Bradyrhizobium in sucrose as a primary source of $\mathrm{C}$ was not expected, since the genus reportedly lacks the invertase enzyme, which is necessary for cells to metabolize sucrose, rhamnose and trehalose (Vincent 1977;

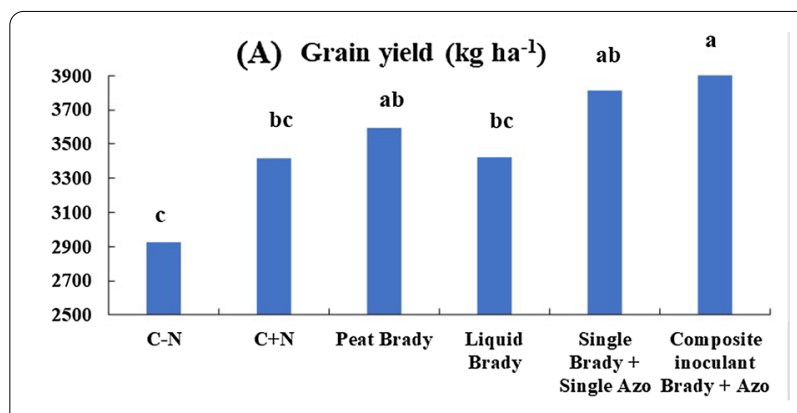

(B) Total $\mathrm{N}$ in grains $\left(\mathrm{kg} \mathrm{N} \mathrm{ha}{ }^{-1}\right)$

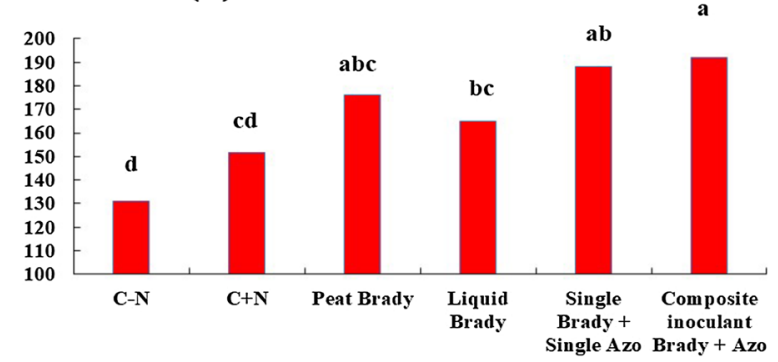

Fig. 2 A Grain yield and (B) total N accumulated in soybean grains resulting from single inoculation with peat and liquid inoculant of Bradyrhizobium, in co-inoculation with single Bradyrhizobium and single Azospirillum and with the co-inoculant carrying both Bradyrhizobium and Azospirillum. Data represent the means of five field experiments, each with six replicates and when followed by the same letter are not statistically diferente (Duncan, $p<5 \%$ )

Martinez-Drets and Arias 1974). For that reason, sucrose has been used by some inoculant industries as a cell protector of soybean Bradyrhizobium, and not as a C source.

One hypothesis to explain the good growth observed in our experiments could be the possible hydrolysis of sucrose by hydrogen ions $\left(\mathrm{H}^{+}\right)$derived from the dissociation of the molecule at high temperatures, in the process of autoclaving the culture medium. Another hypothesis is that, even with low dissociation, the remaining sucrose would be able to provide protection to the cells, favoring survival and contributing to greater cellular concentration. It is also important to search in the genome of the two strains of Bradyrhizobium used in this study (Hungria et al. 2018) for possible alternative routes of assimilation of sucrose. Mannitol is broadly known as an appropriate source of $\mathrm{C}$ for Bradyrhizobium and the same occurs with glycerol, which is also the source of preference in several inoculant industries (Vincent 1970, 1977; Lopreto et al. 1972; Balatti 1992; Balatti and Freire 1996; Hungria et al. 2016).

The growth of $A$. brasilense was maximized in a culture medium containing malic acid and maleic acid; in fact, the preferred use of malic acid by this species is broadly known (Döbereiner et al. 1995). However, the high cost of maleic acid makes it unattractive for utilization in the 
commercial production of inoculants. There was also good growth in the presence of mannitol, which is justified by the presence of the enzyme mannitol dehydrogenase (Westby et al. 1983). According to Döbereiner and Pedrosa (1987), and Hartmann and Baldani (2006), sucrose would not be a good source of $\mathrm{C}$ for $A$. brasilense; however, in our study, good growth was verified with this source. As for Bradyrhizobium, it is necessary to investigate whether the growth of $A$. brasilense is due to partial hydrolysis of sucrose, or to metabolic pathways for the use of sucrose.

Brazil plays an increasingly prominent role in the international agricultural scenario due to the use of inoculants in soybean crops, with high economic and environmental returns for farmers and for the country (Hungria et al. 2006, 2007; Hungria and Mendes 2015; Hungria and Nogueira 2019). Increasing success has been obtained after the deployment of the technology of co-inoculation with Bradyrhizobium spp. and A. brasilense in 2013, with doubled grain yield benefits culminating in the commercial launch of a technological package containing the two bacteria separately (Hungria et al. 2013b, 2015; Barbosa et al. 2021; Santos et al. 2021). In a recent a meta-analysis of 48 publications covering field trials at 38 different locations in Brazil, Barbosa et al. (2021) detected statistically significant increases in grain yield and other plant growth parameters due to the co-inoculation. In addition, the main published studies in Brazil were recently compiled by Santos et al. (2021), and as an example, the studies of Ferri et al. (2017) and Galindo et al. (2018) indicated increases in grain yield due to the co-inoculation of 20.3 and $11.2 \%$, respectively, compared to the inoculation exclusively with Bradyrhizobium. In the co-inoculation, although there may be a contribution from $A$. brasilense via biological nitrogen fixation, the benefits provided by strains Ab-V5 and Ab-V6 have been mainly attributed to the production of phytohormones, resulting in expressive increases in several root parameters (Fukami et al. 2018b; Rondina et al. 2020). Root growth increases also favor the uptake of fertilizers (Galindo et al. 2021). There are also reports of induction of plant tolerance to abiotic stresses (Fukami et al. 2017; 2018a).

In addition to scientific evidence, the success of a new agricultural technology depends on large-scale proof of benefits to farmers. In this context, field extension efforts have been applied for three growing seasons in the state of Paraná, Brazil, with the establishment of reference units (RU) and field days. In the first year, 2017/2018, $37 \mathrm{RU}$ were installed in 23 municipalities, assisting 665 farmers. Co-inoculation with Bradyrhizobium spp. and $A$. brasilense resulted in average increase in grain yield of $228 \mathrm{~kg} \mathrm{ha}^{-1}$ with profit of R\$ $263.4 \mathrm{ha}^{-1}$ ( U\$ 70 in $05 / 18$ ) in relation to the single inoculation with
Bradyrhizobium (Nogueira et al. 2018). In the following season (2018/2019), in 61 RU located in 46 municipalities assisting 925 producers, co-inoculation resulted in average yield increase of $259 \mathrm{~kg} \mathrm{ha}^{-1}$, and net profit of $\mathrm{R} \$$ $296.00 \mathrm{ha}^{-1}$ ( U\$ 76 in 05/19) (Prando et al. 2019) and, in the third season $(2019 / 2020)$, these numbers were of $63 \mathrm{RU}$, in 54 municipalities, assisting 636 farmers, average gain of $266 \mathrm{~kg} \mathrm{ha}^{-1}$ and profit of R $\$ 348.23 \mathrm{ha}^{-1}$ ( U\$ 64 on $05 / 20$ ) (Prando et al. 2020). The large-scale confirmation of benefits explains the widespread adoption of co-inoculation in the country in a short time, estimated at $15 \%$ of the entire cultivated area in 2018/2019, increasing to 25\%, or almost 9 million ha in 2019/2020 (Santos et al. 2021).

The success of co-inoculation in Brazil finds limitations in the use of microorganisms packaged separately, with a great demand, mainly by medium and small farmers, for composite inoculants. This is just one example, as the demand for composite inoculants, containing microorganisms with different metabolic functions, grows internationally (Santos et al. 2019). However, the development of inoculants containing microorganisms with different metabolic needs and growth rates is challenging. In this study, the feasibility of combining microorganisms with different metabolic needs and growth rates was demonstrated, through the development of a proper formulation composed by viable $\mathrm{C}$ sources and definition of times of inoculation. In our study, the preferred $C$ sources for Bradyrhizobium were glycerol and mannitol, and for $A$. brasilense malic acid. In addition, as the growth rates were different, the best results were obtained with the inoculation of the fast-growing $A$. brasilense on the third day of growth of Bradyrhizobium.

In five field trials, the developed composite inoculant showed performance similar to that of co-inoculation with the two microorganisms provided separately, resulting in average increase in grain yield of $502 \mathrm{~kg} \mathrm{ha}^{-1}$, or $14.7 \%$ in relation to the liquid inoculant containing only Bradyrhizobium (Fig. 2).

It should also be noted that there is great concern in the agribusiness sector about the low levels of protein in soybean grains and there are indications that the $\mathrm{N}$ from the BNF is more easily translocated to grains than the N-fertilizer (Hungria and Neves 1987; Kaschuk et al. 2010; Hungria et al. 2020). This was confirmed in the field trials performed in our study, with an average increment of $16.4 \%$ in the total $\mathrm{N}$ accumulated in the grains in response to inoculation and co-inoculation (Fig. 2).

The development of composite microbial inoculants and extension activities with the farmers showing the benefits of microbial inoculants should be encouraged globally, in view of several reports, including this one, 
showing agronomic, economic, and environmental benefits by the replacement of chemical fertilizers.

\section{Supplementary Information}

The online version contains supplementary material available at https://doi. org/10.1186/s13568-021-01230-8.

Additional file 1: Table S1. Geographic coordinates, climate conditions, properties and classification of the soil in each site where the field experiments were performed. Table S2. Soil chemical properties in the 0-20 e 20-40 cm layers in the experimental sites before sowing. Table S3. Soil chemical characterization and granulometry in the $0-20$ e $20-40 \mathrm{~cm}$ layers and population of rhizobia symbionts of soybean and of diazotrophic bacteria in the 0-10 cm layer in the sites of the experiments before sowing. Table S4. Agronomic information about the field experiments.

\section{Acknowledgements}

Authors thank to Dr. Ricardo Silva Araujo for important suggestions on the manuscript. Research group supported by the INCT-Plant-Growth Promoting Microorganisms for Agricultural Sustainability and Environmental Responsibility (CNPq 465133/2014-2, Fundação Araucária-STI 043/2019, CAPES).

\section{Authors' contributions}

MVCG, MAN, MH—participated in all stages of study. All authors read and approved the final manuscript.

\section{Funding}

Partially funded by a public-private project of technical cooperation established since 2009 (Technical Collaboration of Embrapa Soja-Total Biotecnologia No 20900.09/0080-2). Studies supported by the INCT-Plant-Growth Promoting Microorganisms for Agricultural Sustainability and Environmental Responsibility (CNPq 465133/2014-2, Fundação Aaucária-STI 043/2019, (APES).

\section{Availability of data and materials}

All datasets generated or analyzed during this study are included in the manuscript, and complementary dataset will be available upon request to the corresponding author.

\section{Declarations}

\section{Ethics approval and consent of participation}

The study has not involved any human or animal participation or data.

\section{Consent for publication}

All authors gave the consent for publication.

\section{Competing interests}

Authors declare no competing interests regarding the data or the manuscript. The final formulation developed is registered by Total Biotecnologia/Biotrop.

\section{Author details}

'Department of Biotechnology, Universidade Estadual de Londrina, C.P. 10011, Londrina, Paraná 86057-970, Brazil. ${ }^{2}$ Soil Biotechnology Laboratory, Embrapa Soja, C.P. 231, Londrina, Paraná 86001-970, Brazil.

Received: 12 December 2020 Accepted: 11 May 2021

Published online: 22 May 2021

\section{References}

Balatti, AP (1992) Producción de inoculantes para leguminosas: Tecnología de las fermentaciones aplicada a los géneros Rhizobium y Bradyrhizobium. La Plata, Argentina, Editora Trabuco, pp 63-91
Balatti, AP, Freire JRJ (1996). Legume inoculants: Selection and characterization of ctrains - Production, use and management. La Plata, Argentina, Editorial Kingraf, pp 148

Barbosa JZ, Hungria M, Sena JVS, Poggere G, Reis AR, Corrêa RS (2021) Metaanalysis reveals benefits of co-inoculation of soybean with Azospirillum brasilense and Bradyrhizobium spp. in Brazil. Appl Soil Ecol 163:103913. https://doi.org/10.1016/.apsoil.2021.103913

Bashan Y (1998) Inoculants of plant growth-promoting bacteria for use in agriculture. Biotechnol Adv 16:729-770. https://doi.org/10.1016/S07349750(98)00003-2

Bellabarba A, Fagorzi C, di Cenzo GC, Pini F, Viti C, Checcucci A (2019) Deciphering the symbiotic plant microbiome: translating the most recent discoveries on rhizobia for the improvement of agricultural practices in metal-contaminated and high saline lands. Agron J 9(9):529. https://doi. org/10.3390/agronomy9090529

Burton JC, Curley RI (1965) Comparative efficiency of liquid and peat-base inoculants on field-grown soybean (Glycine max). Agron J 57:379-381

de Bruijn FJ (2015) ed. Biological nitrogen fixation. Hoboken, New Jersey: Wiley. 2:1009-1023. https://doi.org/10.1002/9781119053095

Döbereiner J, Marriel I, Nery M (1976) Ecological distribution of Spirillum lipoferum Beijerinck. Can J Microbiol 22:1464-1473. https://doi.org/10. $1139 / \mathrm{m} 76-217$

Döbereiner J, Pedrosa FO (1987) Nitrogen-fixing bacteria in nonleguminous crop plants. Madison, Science Tech Publishers Springer-Verlag, pp 155 ISBN 3540-1796-90

Döbereiner J, Baldani VLD, Baldani Jl (1995) Como isolar e identificar bactérias diazotróficas de plantas não leguminosas. Itaguaí-RJ, Brasília-DF, Brazil, Embrapa SPI, pp 60 ISBN 85850076-56

Embrapa Soja (2013) Tecnologias de produção de soja - Região Central do Brasil 2014. Embrapa Soja, Sistemas de Produção 16. Londrina, Brazil, Embrapa Soja, pp 265 ISSN 1677-8499

Fehr WR, Caviness CE (1977) Stages of soybean development. Ames, US, lowa State University Special Report 80, p 12

Feigl F, Anger V (1972) Spot tests in inorganic analysis, 6th edn. Elsevier, Amsterdam, p 668

Ferri GC, Braccini AL, Anghinoni FBG, Pereira LC (2017) Effects of associated co-inoculation of Bradyrhizobium japonicum with Azospirillum brasilense on soybean yield and growth. Afr J Agric Res. 12:6-11. https://doi.org/10. 5897/AJAR2016.11711

Fukami J, Cerezini P, Hungria M (2018) Azospirillum: benefits that go far beyond biological nitrogen fixation. AMB Express 8:73. https://doi.org/10.1186/ s13568-018-0608-1)

Fukami J, De La Osa C, Ollero FJ, Megías M, Hungria M (2017) Co-inoculation of maize with Azospirillum brasilense and Rhizobium tropici as a strategy to mitigate salinity stress. Funct Plant Biol 45:328-339. https://doi.org/10. 1071/FP17167

Fukami J, Ollero FJ, De La Osa C, Valderrama-Fernández R, Megías G, Hungria M (2018) Antioxidant activity and induction of mechanisms of resistance to stresses related to the inoculation with Azospirillum brasilense. Arch Microbiol 200:1191-1203. https://doi.org/10.1007/s00203-018-1535-x

Galindo FS, Teixeira Filho MCM, Buzetti S, Ludkiewicz GZM, Rosa PAL, Tritapepe CA (2018) Technical and economic viability of co-inoculation with Azospirillum brasilense in soybean cultivars in the Cerrado. Rev Bras Eng Agric Ambient 22:51-56. https://doi.org/10.1590/1807-1929/agriambi. V22n1p51-56

Galindo FS, Silva EC, Pagliari PH, Fernandesa GC, Rodrigues WL, Giagini ALC, Baratella EB, Silva Júnior CA, Moretti Neto MJ, Silva VM, Muraoka T, Teixeira Filho MCM (2021) Nitrogen recovery from fertilizer and use efficiency response to Bradyrhizobium sp. and Azospirillum brasilense combined with N rates in cowpea-wheat crop sequence. Appl Soil Ecol 157:103764. https://doi.org/10.1016/j.apsoil.2020.103764

Hartmann A, Baldani II (2006) The genus Azospirillum. In: Dworkin M, Falkow S, Rosenberg E Schleifer KH, Stackebrandt E (eds) The Prokaryotes. Proteobacteria: Alpha and Beta Subclasses. New York, Springer New York, p 15-140

Hungria M, Neves MCP (1987) Partitioning of nitrogen from biological fixation and fertilizer in Phaseo/us vulgaris. Physiol Plant 69:55-63. https://doi.org/ 10.1111/j.1399-3054.1987.tb01945.x

Hungria M, Campo RJ, Mendes IC, Graham PH (2006) Contribution of biological nitrogen fixation to the $\mathrm{N}$ nutrition of grain crops in the tropics: the success of soybean (Glycine max L. Merr.) in South America. In: Singh RP, Shankar 
$\mathrm{N}$, Jaiwal PK (eds). Nitrogen nutrition and sustainable plant productivity. Houston, Texas: Studium Press, LLC, pp 43-93. ISBN: 1-933699-00-0

Hungria M, Campo RJ, Mendes IC (2007) A importância do processo de fixação biológica do nitrogênio para a cultura da soja: componente essencial para a competitividade do produto brasileiro. Embrapa Soja, Documentos 283. Londrina, Embrapa Soja, pp 80 ISSN 1516-781X

Hungria M, Campo RJ, Souza EM, Pedrosa FO (2010) Inoculation with selected strains of Azospirillum brasilense and A. lipoferum improves yields of maize and wheat in Brazil. Plant Soil 331:413-425. https://doi.org/10.1007/ s11104-009-0262-0

Hungria M (2011) Inoculação com Azospirillum brasilense: inovação em rendimento a baixo custo. Embrapa Soja, Circular Técnica 325. Londrina, Brazil, Embrapa Soja, 36 p. ISSN:2176-2937

Hungria M, Nogueira MA, Araujo RS (2013) Co-inoculation of soybeans and common beans with rhizobia and azospirilla: strategies to improve sustainability. Biol Fertil Soils 49:791-801. https://doi.org/10.1007/s00374-012-0771-5

Hungria M, Mendes IC, Mercante FM (2013a) A fixação biológica do nitrogênio como tecnologia de baixa emissão de carbono: avaliação nas culturas do feijoeiro e da soja. Embrapa Soja, Documentos 337. Londrina, Embrapa Soja, pp 22. ISSN 2176-2937

Hungria M, Mendes IC (2015) Nitrogen fixation with soybean: the perfect symbiosis? In: de Bruijn FJ (ed) Biological Nitrogen Fixation. Hoboken, New Jersey, Wiley, pp 1009-1023. https://doi.org/10.1002/9781119053095.ch99

Hungria M, Nogueira MA, Araujo RS (2015) Soybean seed co-inoculation with Bradyrhizobium spp. and Azospirillum brasilense: a new biotechnological tool to improve yield and sustainability. Amer J Plant Sci 6:811-817. https://doi. org/10.4236/ajps.2015.66087

Hungria M, O'Hara GW, Zilli JE, Araujo RS, Deaker R, Howieson JG (2016) Isolation and growth of rhizobia. In: Howieson JG, Dilworth MJ (eds) Working with rhizobia. Canberra, Australia, Australian Center for International Agricultural Research (ACIAR), pp 39-60

Hungria M, Ribeiro RA, Nogueira MA (2018) Draft genome sequences of Azospirilum brasilense strains $\mathrm{Ab}-\mathrm{V} 5$ and $\mathrm{Ab}-\mathrm{V} 6$, commercially used in inoculants for grasses and 1egumes in Brazil. Genome Announc 6(20):e00393-e418. https://doi.org/10.1128/genomeA.00393-18

Hungria M, Nogueira MA (2019) Tecnologias de inoculação da cultura da soja: Mitos, verdades e desafios. In: Boletim de Pesquisa Fundação MT 19. Rondonópolis, Fundação MT, p 50-62

Hungria M, Nogueira MA, Campos LM, Menna P, Brandi F, Ramos YG (2020) Seed pre-inoculation with Bradyrhizobium as time-optimizing option for largescale soybean cropping systems. Agron j 112:5222-5236. https://doi.org/10. 1002/agj2.20392

Juge C, Prévost D, Bertrand A, Bipfubusa M, Chalifour FP (2012) Growth and biochemical responses of soybean to double and triple microbial associations with Bradyrhizobium, Azospirillum and arbuscular mycorrhizae. Appl Soil Ecol 61:147-157. https://doi.org/10.1016/j.apsoil.2012.05.006

Kaschuk G, Leffelaar PA, Giller KE, Alberton O, Hungria M, Kuyper TW (2010) Responses of grain legumes to rhizobia and arbuscular mycorrhizal fungi: a meta-analysis of potential photosynthate limitation of symbioses. Soil Biol Biochem 42:125-127. https://doi.org/10.1016/J.soilbio.2009.10.017

Lopreto CR, Mazza LA, Balatti AP (1972) Influencia de los componetes Del medio de cultivo sobre el tiempo de generación de uma cepa de Rhizobium japonicum. An Soc Cient Arg 193:35-47

Malusá E, Vassilev N (2014) A contribution to set a legal framework for biofertilisers. Appl Microbiol Biotechnol 98(15):6599-6607. https://doi.org/10.1007/ s00253-014-5828-y

MAPA (Ministério da Agricultura, Pecuária e Abastecimento) (2011) INSTRUÇ̃̃o NORMATIVA No 13, de 24 de março de 2011. (https://www.gov.br/agric ultura/pt-br/assuntos/insumos-agropecuarios/insumos-agricolas/fertilizan tes/legislacao/in-sda-13-de-24-03-2011-inoculantes.pdf/view). Accessed 13 May 2020

Martinez-Drets G, Arias A (1974) Enzymatic basis for differentiation of Rhizobium into fast and slow-growing groups. J Bacteriol 109:467-470

Nogueira MA, Prando AM, Oliveira AB, Lima D, Conte O, Harger N, Oliveira FT, Hungria M (2018) Ações de transferência de tecnologia em inoculação/ coinoculação com Bradyrhizobium e Azospirillum na cultura da soja na safra 2017/18 no estado do Paraná. Embrapa Soja, Circular Técnica 143. Londrina, Brazil, Embrapa Soja, pp 15 ISSN 2176 -2864

O'Hara GW, Hungria M, Woomer P, Howieson JG (2016) Counting rhizobia. In: Howieson JG, Dilworth MJ (eds). Working with rhizobia. Canberra, Australia, Australian Center for International Agricultural Research (ACIAR), pp 109-124. ISBN 9781925436174

Prando AM, Oliveira AB, Lima D, Possamai EJ, Reis EA, Nogueira MA, Hungria M, Harger N, Conte O (2019) Coinoculação da soja com Bradyrhizobium e Azospirillum na safra 2018/2019 no Paraná. Embrapa Soja, Circular Técnica 156. Londrina, Brazil, Embrapa Soja, pp 19 ISSN 1516-7860

Prando AM, Oliveira AB, Lima D, Possamai EJ, Reis EA, Nogueira MA, Hungria M, Conte O (2020) Coinoculação da soja com Bradyrhizobium e Azospirillum na safra 2019/20 no Paraná. Embrapa Soja, Circular Técnica 166. Londrina, Brazil, pp 22 ISSN 2176-2864

Rondina ABL, Sanzovo AWS, Guimarães GS, Wendling JR, Nogueira MA, Hungria M (2020) Changes in root morphological traits in soybean co-inoculated with Bradyrhizobium spp. and Azospirillum brasilense or treated with $A$. brasilense exudates. Biol Fertil Soils 56:537-549. https://doi.org/10.1007/ s00374-020-01453-0

Sá JCM, Lal R, Cerri CC, Lorenz K, Hungria J, Carvalho PCC (2017) Low-Carbon agriculture in South America to mitigate global climate change and advance food security. Environ Int 98:102-112. https://doi.org/10.1016/j.envint.2016. 10.020)

Santos MS, Nogueira MA, Hungria M (2019) Microbial inoculants: reviewing the past, discussing the present and previewing an outstanding future for the use of beneficial bacteria in agriculture. AMB Express 9:205. https://doi.org/ 10.1186/s13568-019-0932-0

Santos MS, Rodrigues TF, Ferreira E, Megías M, Nogueira MA, Hungria M (2020) Method for recovering and counting viable cells from maize seeds inoculated with Azospirillum brasilense. J Pure Appl Microbiol 14(1):195-204. https://doi.org/10.22207/JPAM.14.1.21

Santos MS, Nogueira MA, Hungria M (2021) Outstanding impact of Azospirillum brasilense strains Ab-V5 and Ab-V6 on the Brazilian agriculture: lessons that farmers are receptive to adopt new microbial inoculants. Rev Bras Ciênc Solo. 45:200128. https://doi.org/10.36783/18069657rbcs20200128

Segnini A, Santos LM, Silvaii WTL, Martin-Neto L, Borato EE, Melo WJ, Bolonhezi D (2008) Estudo comparativo de métodos para a determinação da concentração de carbono em solos com altos teores de Fe (Latossolos). Quim Nova 31:94-97. https://doi.org/10.1590/S0100-40422008000100020

Silva FC (ed) (2009). Manual de análises químicas de solos, plantas e fertilizantes. 2 ed. Brasília, Brazil, Embrapa Informação Tecnológica, pp 627. ISBN: 978-85-7383-430-7

Teixeira PC, Donagema GK, Fontana A, Teixeira WG (ed) (2017) Manual de métodos de análise de solos. $3^{\text {rd }}$ ed. Brasília, Brasil, Embrapa, pp 574. ISBN 978-85-7035-771-7

USDA (United States Department of Agriculture) (2000) World agricultural production (Circular Series WAP 3-20 March 2020). Disponível em: (https:// apps.fas.usda.gov/psdonline/circulars/production.pdf). Accessd 1 April 2020

van Raij B, Andrade JC, Cantarella H, Quaggio JA (2001) Análise química para avaliação da fertilidade de solos tropicais. Campinas, Brazil, Instituto Agronômico de Campinas, pp 285. ISBN 85-85564-05-9

Vincent JM (1970) A manual for the practical study of root-nodule bacteria. International Biological Programme Handbook 15. Oxford, Blackwell, pp 170

Vincent JM (1977) Rhizobium: general microbiology. In: Hardy RWF, Silver W (eds) A treatise on dinitrogen fixation. Wiley, New York, pp 277-366

Westby CA, Cuthail DS, Vigil GV (1983) Metabolism of various carbon sources by Azospirillum brasilense. J Bacteriol 156:1369-1372

\section{Publisher's Note}

Springer Nature remains neutral with regard to jurisdictional claims in published maps and institutional affiliations. 